\title{
Seroprevalence of hemorrhagic septicemia in buffalo and cattle in flood, irrigated and sandy areas of Punjab, Pakistan
}

\author{
Mushtaq Ahmad ${ }^{1,4}$, Mubashar Aziz ${ }^{2}$, Muhammad Tarique Tunio ${ }^{1}$, \\ Rashid ur Rehman ${ }^{3}$, Abdul Rehman ${ }^{4}$, Kashif ur Rehman ${ }^{4 *}$, Abdul \\ Hameed $^{4}$, Tariq Naveed ${ }^{2}$, Muhammad Tanveer ${ }^{4}$ and Muhammad Ali ${ }^{2}$ \\ 1. Department of Agricultural Sciences, Faculty of Sciences, Allama Iqbal Open University, Islamabad-Pakistan \\ 2. Department of Pathobiology, Faculty of Veterinary Sciences, Bahauddin Zakariya University, Multan- \\ Pakistan \\ 3. Nanjing Tech University, Nanjing, P.R-China \\ 4. Livestock and dairy development department, Poultry Research Institute, Rawalpindi, Punjab-Pakistan \\ *Corresponding author's email: kashifrehman@webmail.hzau.edu,drkashif706@hotmail.com \\ Citation \\ Mushtaq Ahmad, Mubashar Aziz, Muhammad Tariq Tunio, Rashid ur Rehman, Abdul Rehman, Kashif ur \\ Rehman, Abdul Hameed, Tariq Naveed, Muhammad Tanveer and Muhammad Ali. Seroprevalence of \\ hemorrhagic septicemia in buffalo and cattle in flood, irrigated and sandy areas of Punjab, Pakistan. Pure and \\ Applied Biology. Vol. 7, Issue 4, pp1234-1243. http://dx.doi.org/10.19045/bspab.2018.700143
}

\begin{tabular}{llll}
\hline \hline Received: 18/05/2018 & Revised: 19/08/2018 & Accepted: 23/08/2018 & Online First: 31/08/2018 \\
\hline \hline
\end{tabular}

\section{Abstract}

Hemorrhagic septicemia (HS) is an acute, fatal, and septicemic disease of cattle and buffalo caused by Pasteurella multocida. It is particularly important in the tropical regions of the world, especially in Asia and Africa. The study was conducted to record the HS disease prevalence rate in different areas (flood, irrigated and sandy), species of animals, and different age groups. Moreover, the antibody titer against HS of vaccinated and nonvaccinated animals (cattle and buffalo) in different areas against HS disease. Morbidity, mortality, and case fatality rate (CFR) due to HS disease in the different animal population (cattle and buffalo), age groups (young and adult), various areas (flood, irrigated and sandy) and vaccinated and unvaccinated animal groups. It can be concluded from the present investigation that HS is endemically occurring in cattle and buffalo. The mean of morbidity, mortality and CFR in young buffalo $(12.56 \%, 22.44 \%$, and $40.44 \%)$ and adult buffalo $(0.94 \%, 2.82 \%$ and $25.68 \%)$ higher than young cattle $(2.42 \%, 6.46 \%, 28.74 \%)$ and adult cattle $(0.54 \%, 1.97 \%$ and $17.63 \%)$, which shows that buffalos are more susceptible of disease as compared to the cattle. Moreover, the young population of buffalo and cattle highly affected (morbidity, mortality, and CFR) of HS as compared with the adult stock. It was also noted that the morbidity, mortality, CFR was greater in flood area $(7.78 \%, 13.95 \%$, and $39.05 \%)$, and lesser in the sandy area $(0.84 \%, 3.76 \%$, and $11.84 \%)$. The comparative value of GMT against HS, deducted with IHA test both for cattle and buffalo, and it was noted that GMT in vaccine status and category of animals showed that it was higher in vaccinated animal than nonvaccinated animal population. Moreover, the GMT was higher in the sandy area as compared with flood and irrigated area. Furthermore, the GMT for vaccinated buffalo was lesser as compared to the vaccinated cattle making them more susceptible to the disease.

Keywords: Buffalo; Case fatality rate; Cattle; Hemorrhagic septicemia; Mortality

Introduction

Pakistan is an agricultural country, livestock and dairy farming plays a major role in the economy of Pakistan [1, 2]. Livestock is the sub-sector of agriculture and its share in agriculture's GDP is round 
about $58.3 \%$ and $11.4 \%$ of the total GDP of Pakistan during the year 2016-17 compared to $58.3 \%$ and $11.6 \%$ during the corresponding last year respectively. Livestock revenue increased from Rs. 1288 billion (2015-16) to Rs. 1333 billion (201617). The above picture depicted that $3.4 \%$ increase during the last year. Livestock share in the economy of Pakistan may be seen because there are round about 8 million families being involved in the livestock sector, generating $35 \%$ of their income from the livestock production [3, 4]. In Pakistan, there are vast numbers of cattle and buffalo population (41.2 million \& 35.6 million respectively) [5]. Another report indicated that annual beef production in Pakistan was 1.6 million tons while milk production was 43.6 million tons [6].

In Pakistan farmers mainly rely on their animal's income for their survival and it is reflected annually in GDP of Pakistan. Farmers are frequently facing many problems which affect the income of the farmers due to certain hurdles such as the onset of infectious disease, duration of illness of animals, nutrition costs and vaccination costs [7]. Previously due to five economical endemic diseases like HS, FMD, Rinder Pest, Anthrax and Black Leg $58.7 \%$ deaths reported [8]. It was observed during participatory disease surveillance in Karachi that HS has higher economic losses than FMD due to higher mortality rate [9]. The morbidity losses due to HS considered $23 \%$ of the total losses and mortality losses contributed $77 \%$ of the total losses. The share of calves was round about $74.8 \%$ of the total losses due to HS disease [10]. The prevalent serotyping of Pasteurella multocida causing Hemorrhagic Septicemia (HS) is listed as B disease i.e B2 (Asian Type) E2 (African Type). Other serotypes reported are A (1), A (1,3), A (4), B (1), B (2, 5), B (3, 4), E (2, 5), F (3), F (3, 4) [11]. HS is mostly the disease of river valleys and case reported mostly from the Delta of South East Asia among the buffalo $[12,13]$.
District Muzaffar Garh (M. Garh) have cattle (1.436), buffalo (0.647), sheep (0.441), goat (0.994) Million respectively [14]. District M. Garh is situated B/w River Chanab, and River Indus in the form of a strip and these rivers pass along the eastern and western borders of the district respectively. District M. Garh has extreme hot and cold climate, and due to river access, some parts are flooded every year $[14,15]$. Therefore, disease outbreak risk of HS disease in such areas is remaining every year in flood areas, so it is imperative to follow the better vaccination strategies of animals especially living in flood areas to combat the outbreak of HS disease. In some areas of Punjab and North West Frontier Post, study on seroprevalence of Hemorrhagic Septicemia (HS) was being done in cattle and buffalo $[12,16]$. In another study, Antibody titer in cattle with the alum-precipitated vaccine was monitored [15, 17]. Whereas, the routine vaccination without monitoring their efficacy (antibody titer) is the whole problem of L\&DD Department Punjab. Therefore, an epidemiological investigation, in the present study was designed. The primary objective of this investigation was, therefore, to evaluate the prevalence of HS disease and antibody titer against HS in cattle and buffalo in Dist. M. Garh. Moreover, affects of the various risk factor were studied on the frequency of HS disease outbreak.

\section{Materials and methods \\ Study area}

This project was designed to examine in the area of District M. Garh. Muzaffargarh is situated in Southern Punjab Province, almost exact center of Pakistan. The area is spread over $8435 \mathrm{~km}^{2}$, it forms a strip between river Chenab in the east and river Indus in west district Multan and Khanewal are present on the eastern side of the district M. Garh while on western side D. G. Khan district, on north side district Layyah and south side district Bahawalpur is present. District M. Garh has four tehsils as Kot Addu, Ali Pur, Jatoi and M. Garh and in the 
study different UC's of all these tehsils were randomly selected.

During the monsoon of 2010, almost 50\% population of people and animals were mostly affected by the flood. The study was carried out in cattle and buffalo (young and adult) found in different areas (flood area, irrigated area, and sandy area) to determine the prevalence of HS and its morbidity, mortality, and CFR. Whereas, different risk factors like housing, feeding, and watering of the animals in these areas were also studied. The serum samples were also analyzed to check the antibody titer of the vaccinated and nonvaccinated animals of these different areas.

\section{Sampling strategy}

Two groups of cattle and buffalo vaccinated and nonvaccinated animals against HS disease were selected. The blood samples from cattle and buffalo were collected from the flood, sandy and somewhat marshy areas of District M. Garh $5 \mathrm{ml}$ blood was collected from each animal, the sample was kept for $12 \mathrm{hr}$. in a slanting position at room temperature for the collection of required serum samples and was stored serum at -20 ${ }^{\circ} \mathrm{C}$. The antibody titer of the vaccinated and nonvaccinated animals was checked by Indirect Hemagglutination Test (IHA).

\section{Population under study}

Sero-prevalence of HS was done in the area of district M. Garh to understand the disease prevalence and economic losses due to a disease outbreak. Randomly ten villages were selected from 3 different areas as flood area, irrigated area and the sandy area from four Tehsils of District M. Garh (Kot Adu, Alipur, Jatoi and M. Garh. The total population of animals from these areas selected 4533 having 2614 cattle and 1919 buffalo. Total 2359 vaccinated and 2174 not inoculated animals were studied (Table1 \& 2). From the study area, ten farmers were randomly selected for data collection from each village and each Union Council level, ten villages were selected randomly.10 villages further subdivided into vaccinated and nonvaccinated groups (animals of First 5 villages were vaccinated, and other five were not vaccinated).

Each farmer of different villages from all areas under study was interviewed, and by using proportional piling and seasonal calendar, data was collected on the prescribed questionnaire. Further 200 serum samples were taken from each area, 50 samples were collected from vaccinated, and 50 nonvaccinated animals from cattle and buffalo of that respective area and their antibody titer was checked against HS disease.

\section{Research design}

The study area is categorized into three zones that flood area, irrigated area, and sandy area. From each area 10 villages were selected, from each village of each area, 10 farmers were randomly selected of which five were vaccinated and five nonvaccinated. Mortality rates, Morbidity rate, and CFR were observed in different animal population (cattle and buffalo), age groups (young and adult), areas (flood, irrigated and sandy). After blood sample collection from cattle and buffalo, further study was done in M. Garh Disease Diagnostic Laboratory, Livestock, and Dairy Development Department. Antibody titer by IHA test of serum samples was performed.

\section{Serological analysis}

Antibodies against Pasteurella multocida were measured by indirect hemagglutination test (IHA) using human blood group ' $\mathrm{O}$ ' $[\mathbf{1 6}, \mathbf{1 8}]$. Briefly, two-fold dilutions of the test sera starting from 1:5 to 1:640 were made in normal saline using microtiter plates (96 wells) and added the $25 \mu 1$ amount to all the wells of plate except those of column 11 and 12 which served as control. First four wells (A-D) of column 11 were added with known negative serum and last four wells (E-H) with the known positive serum. Sensitized RBC's (1\%) was added in equal amounts $(25 \mu 1)$ to all the wells of the plate so that column 12 served as a control for the RBC's. The plates were incubated at room temperature for two hours, and the observations were recorded. 
After that, the plates were kept re-incubated under refrigeration for overnight, shaken vigorously, allowed to resettle and were read again. The IHA test was performed as formerly reported [18-20]. Results were interpreted as positive (no bead formation) or negative (bead formation with sharp, clear margins). The IHA antibody titers against HS were converted into geometric mean titers (GMT) for each group [19-21].

Statistical analysis

The statistical analysis was performed by SPSS 16.0 (SPSS Inc., Chicago, IL, USA). The results of all experiments were analyzed analysis of variance (ANOVA), followed by Latin square design (LSD) allpairwise comparisons test to compare the significance $(\mathrm{P})$ between the means of morbidity, mortality and CFR of different groups (young and adult; buffalo and cattle; vaccinated and nonvaccinated; flood, irrigated and sandy areas). $\mathrm{P}<0.05$ was considered to indicate a significant difference between the values compared.

\section{Results}

\section{Morbidity, mortality and case fatality in nonvaccinated and vaccinated population}

The morbidity, mortality, and CFR in all three study areas in the nonvaccinated population were $8.42 \%, 4.60 \%$, and $54.64 \%$ respectively while in vaccinated animal's rates were $2.80 \%, 0.76 \%$, and $27.27 \%$ respectively in cattle and buffalo (Table 3). Whereas, from 1919 buffalo in flood, irrigated and sandy areas, morbidity, mortality and case fatality of nonvaccinated animals were $14.33 \%, 9.04 \%$, and $63.08 \%$ respectively while in vaccinated animal $4.74 \%, 1.38 \%$ and $29.18 \%$ respectively (Table 3). Moreover, in cattle population (2614) morbidity, mortality and case fatality of not vaccinated animals in these areas $4.18 \%, 1.42 \%$, and $33.96 \%$ respectively. While in vaccinated cattle morbidity, mortality and CFR were $1.34 \%$, $0.30 \%$ and $22.22 \%$ respectively (Table 3 ).

\section{Morbidity, mortality and case fatality rates in flood area}

Mortality, morbidity and case fatality among nonvaccinated young buffalo in flood area was recorded $51.47 \%, 40.44 \%$, $78.57 \%$ while in adult $5.11 \%, 1.80 \%$ and $35.29 \%$ respectively (Table 4$)$. Whereas, in vaccinated young buffalo it was recorded at $22.34 \%, 7.45 \%, 33.33 \%$ while in adult $2.30 \%, 0.38 \%$, and $16.67 \%$ respectively.

The morbidity, mortality, and case fatality in nonvaccinated young cattle was noted at $13.68 \%, 7.37 \%, 53.85 \%$, however, an adult $4.22 \%, 1.61 \%$, and $36.36 \%$ respectively. However, in young vaccinated cattle, it was observed with $10.96 \%, 2.74 \%, 25.00 \%$, while in adult $1.31 \%, 0.44 \%$ and $33.33 \%$ respectively (Table 4).

\section{Morbidity, mortality and case fatality rates in the irrigated area}

Morbidity, mortality and case fatality in nonvaccinated young buffalo recorded $31.88 \%, 18.84 \%, 50.09 \%$, while in adult $4.27 \%, 2.44 \%$ and $57.14 \%$ respectively, while in adult it was $4.27 \%, 2.44 \%$, and $57.14 \%$ respectively (Table 4 ), whereas in vaccinated young buffalo in irrigated area it was observed $9.09 \%, 3.78 \%$, and $41.66 \%$ respectively, while in adult it was $1.59 \%$, $0.32 \%$, and $20.00 \%$ respectively.

Morbidity, mortality and case fatality in nonvaccinated young Cattle recorded $6.41 \%, 2.56 \%, 40.00 \%$, while in adult $3.72 \%, 0.93 \%$ and $25.00 \%$ respectively (Table 4). However, in vaccinated young cattle in recorded irrigated area 4.00, 1.00, and 25.00 respectively, while in adult $1.00 \%, 0.00 \%$ and $0.00 \%$ respectively (Table 4).

\section{Morbidity, mortality and case fatality rates in the sandy area}

Mortality, morbidity and case fatality in young nonvaccinated buffalo in sandy areas was recorded $16.33 \%, 4.84 \%, 30.00 \%$, while in adult it was noted $2.79 \%, 0.69 \%$, and $25.00 \%$ respectively, whereas, in vaccinated young buffalo in sandy area it was $3.71 \%, 0.00 \%, 0.00 \%$ while in adult $0.77 \%, 0.00 \%$ and $0.00 \%$ respectively (Table 4). 
Mortality, morbidity and case fatality in young nonvaccinated cattle in sandy areas was recorded $3.55 \% 1.02 \%, 28.57 \%$, while in adult $2.09 \%, 0.23 \%$ and $11.11 \%$ respectively, whereas, in vaccinated young cattle in sandy area it was $1.00 \%, 0.00 \%$, $0.00 \%$ while in adult $0.00 \%, 0.00 \%$ and $0.00 \%$ respectively (Table 4 ).

\section{Comparison of means of different parameters under investigation}

The comparison of the means presented in (Table 5). It was noted that among the age group the morbidity, mortality and case fatality in young buffalo was $12.56 \%$, $22.44 \%, 40.44 \%$ which was significantly higher as compared to the young cattle except case fatality (28.74\%) which has no significant difference with young buffalo. However, the adult group the morbidity ( $0.94 \%$ in buffalo and $0.54 \%$ in cattle) has no significant difference, whereas the mortality and case fatality was significantly higher in adult buffalo (2.82\% and $25.68 \%$ ) as compared with cattle $(1.97 \%$ and 17.63$)$ (Table 5).

Moreover, the nonvaccinated animal population has significantly higher morbidity, mortality and case fatality $(6.89 \%, 12.13 \%$, and $39.99 \%$ respectively) than vaccinated animal population (1.33, 4.71 and 16.25 respectively) (Table 5).

Furthermore, the morbidity $(7.78 \%, 3.71 \%$, and $0.84 \%$ ) in different areas (food, irrigated and sandy) have no significant difference among them. However, the mortality, case fatality $(13.95 \%, 39.05 \%)$ was significantly higher in flood area, and lesser in the sandy area $(3.76 \%$ and $11.84 \%$ ) (Table 5).

\section{IHA Titer against $\mathrm{HS}$ in various areas}

The flood area nonvaccinated buffalo in flood area the GMT was recorded 6.97 while in vaccinated buffalo recorded 45.16 (Table 6), whereas, GMT in nonvaccinated cattle recorded 8.29 while in vaccinated cattle observed 49 (Table 6). In the irrigated area, the GMT in nonvaccinated buffalo was noted 8.88 , while in vaccinated buffalo it was recorded 45.16 (Table 6). The GMT in nonvaccinated cattle was 8.29 whereas, in vaccinated cattle was 49 (Table 6). However, in the sandy area, the GMT among nonvaccinated buffalo was 13.54 , while in vaccinated buffalo it was noted 47.33 (Table 6). Whereas the GMT in nonvaccinated cattle recorded 10.24 while in vaccinated cattle it was recorded at 47.95 (Table 6).

\section{Discussion}

Hemorrhagic septicemia is a globally significant livestock disease. However, due to poor livestock farm practices, it is more severe in Asia and Africa. The climate change for the animal is important, as the particular breed rearing under adverse environmental conditions or environment, influence the exposure to the disease and cause substantial economic losses to the livestock breeders [22]. This is the first report on seroprevalence of HS disease in changing climate condition (flood, irrigated and sandy) in M. Garh. Moreover, the study was carried out to check the prevalence of HS disease in district M. Garh in different geographical areas (flood, irrigated and sandy) and different age groups (young and adult). The population of animals in district M. Garh was 4533 in which young animals were 1347 while adult animals were 3186 . The seroprevalence of HS in various age group was already investigated in different districts of Pakistan $[12,16]$, whereas in different geographical region or condition were also investigated [13].

In our study area vaccinated animals in flood areas were 657, in irrigated areas were 940 and in the sandy area were 762 while nonvaccinated animals in flood area were 813 , in the irrigated area were 526 and in the sandy area were 835. In another study, animals were selected in towns, small villages, and big villages. The animals were compared regarding the HS disease outbreaks in these different areas $[12,13]$. 
Ahmad et al.

Table 1. Animal population under investigation in irrigated, flood and sandy areas

\begin{tabular}{|c|c|c|c|c|c|c|c|c|c|c|c|c|}
\hline \multirow[b]{2}{*}{ Vaccine status } & \multicolumn{2}{|c|}{ Flood area } & \multirow{2}{*}{$\begin{array}{l}\text { Total } \\
\text { (n) }\end{array}$} & \multicolumn{2}{|c|}{ Irrigated area } & \multirow[b]{2}{*}{ Total } & \multicolumn{2}{|c|}{ Sandy area } & \multirow{2}{*}{$\begin{array}{l}\text { Total } \\
\text { (n) }\end{array}$} & \multicolumn{3}{|c|}{ Total } \\
\hline & Young (n) & $\begin{array}{l}\text { Adult } \\
\text { (n) }\end{array}$ & & $\begin{array}{c}\text { Young } \\
(\mathrm{n})\end{array}$ & $\begin{array}{l}\text { Adult } \\
\text { (n) }\end{array}$ & & $\begin{array}{c}\text { Young } \\
(\mathrm{n})\end{array}$ & $\begin{array}{l}\text { Adult } \\
\text { (n) }\end{array}$ & & $\begin{array}{c}\text { Young } \\
\text { (n) }\end{array}$ & $\begin{array}{l}\text { Adult } \\
\text { (n) }\end{array}$ & $\begin{array}{c}\text { Total } \\
\text { (n) }\end{array}$ \\
\hline Vaccinated & 167 & 490 & 657 & 261 & 679 & 940 & 282 & 480 & 762 & 710 & 1649 & 2359 \\
\hline Nonvaccinated & 231 & 582 & 813 & 147 & 379 & 526 & 259 & 576 & 835 & 637 & 1537 & 2174 \\
\hline Total & 398 & 1072 & 1470 & 408 & 1058 & 1466 & 541 & 1056 & 1597 & 1347 & 3186 & 4533 \\
\hline
\end{tabular}

$\mathrm{n}$ is the number of animals

Table 2. Populations of cattle and buffalo in different areas

\begin{tabular}{|c|c|c|c|c|c|c|c|c|c|c|c|c|c|c|c|}
\hline \multirow{3}{*}{ Vaccine Status } & \multicolumn{4}{|c|}{ Flood area } & \multicolumn{4}{|c|}{ Irrigated area } & \multicolumn{4}{|c|}{ Sand area } & \multirow{3}{*}{$\begin{array}{c}\text { Total } \\
\text { buffalo }\end{array}$} & \multirow{3}{*}{$\begin{array}{l}\text { Total } \\
\text { cattle }\end{array}$} & \multirow{3}{*}{ Total } \\
\hline & \multicolumn{2}{|c|}{ Buffalo (n) } & \multicolumn{2}{|c|}{ Cattle (n) } & \multicolumn{2}{|c|}{ Buffalo (n) } & \multicolumn{2}{|c|}{ Cattle (n) } & \multicolumn{2}{|c|}{ Buffalo (n) } & \multicolumn{2}{|c|}{ Cattle $(\mathrm{n})$} & & & \\
\hline & Young & Adult & Young & Adult & Young & Adult & Young & Adult & Young & Adult & Young & Adult & & & \\
\hline Vaccinated & 94 & 261 & 73 & 229 & 132 & 314 & 129 & 365 & 81 & 130 & 201 & 350 & 1012 & 1347 & 2359 \\
\hline Nonvaccinated & 136 & 333 & 95 & 249 & 69 & 164 & 78 & 215 & 62 & 143 & 197 & 433 & 907 & 1267 & 2174 \\
\hline Total & 230 & 594 & 168 & 478 & 201 & 478 & 207 & 580 & 143 & 273 & 398 & 783 & 1919 & 2614 & 4533 \\
\hline
\end{tabular}

$\mathrm{n}$ is the number of animals 
Table 3. Morbidity mortality and case fatality in buffaloes and cattle's in vaccinated and nonvaccinated animals

\begin{tabular}{|c|c|c|c|c|c|c|c|c|c|c|}
\hline Species & Area & \multicolumn{2}{|c|}{ Population (n) } & $\begin{array}{c}\text { Total } \\
\text { (n) }\end{array}$ & \multicolumn{2}{|c|}{ Morbidity $(\%)$} & \multicolumn{2}{|c|}{ Mortality (\%) } & \multicolumn{2}{|c|}{ Case fatality $(\%)$} \\
\hline & Irrigated & 233 & 446 & 679 & 12.45 & 3.81 & 7.30 & 1.35 & 58.62 & 35.29 \\
\hline \multicolumn{2}{|c|}{ Total } & 907 & 1012 & 1919 & 14.33 & 4.74 & 9.04 & 1.38 & 63.08 & 29.17 \\
\hline \multirow[t]{2}{*}{ Cattle } & Floody & 344 & 302 & 646 & 6.98 & 3.64 & 3.20 & 0.99 & 45.83 & 27.27 \\
\hline & Irrigated & 293 & 494 & 787 & 4.44 & 1.01 & 1.37 & 0.20 & 30.77 & 20.00 \\
\hline
\end{tabular}

$\mathrm{n}$ is the number of animals

Table 4. Morbidity, mortality and case fatality in different areas and age groups

\begin{tabular}{|c|c|c|c|c|c|c|c|c|c|c|}
\hline \multirow[b]{2}{*}{ Areas } & \multirow[b]{2}{*}{ Species } & \multirow[b]{2}{*}{$\begin{array}{c}\text { Vaccination } \\
\text { Status }\end{array}$} & \multicolumn{4}{|c|}{ Young } & \multicolumn{4}{|c|}{ Adult } \\
\hline & & & $\begin{array}{l}\text { Total no. of } \\
\text { animals (n) }\end{array}$ & $\begin{array}{l}\text { Morbidity } \\
(\%)\end{array}$ & $\begin{array}{l}\text { Mortality } \\
(\%)\end{array}$ & $\begin{array}{c}\text { Case } \\
\text { fatality } \\
(\%)\end{array}$ & $\begin{array}{l}\text { Total No of } \\
\text { Animals } \\
(\mathrm{n})\end{array}$ & $\begin{array}{l}\text { Morbidity } \\
(\%)\end{array}$ & $\begin{array}{l}\text { Mortality } \\
(\%)\end{array}$ & $\begin{array}{c}\text { Case fatality } \\
(\%)\end{array}$ \\
\hline \multirow{4}{*}{ Flood Area } & \multirow{2}{*}{ Buffalo } & Nonvaccinated & 136 & 51.47 & 40.44 & 78.57 & 333 & 5.11 & 1.81 & 35.29 \\
\hline & & Vaccinated & 94 & 22.34 & 7.45 & 33.33 & 261 & 2.30 & 0.38 & 16.67 \\
\hline & \multirow{2}{*}{ Cattle } & Nonvaccinated & 95 & 13.68 & 7.37 & 53.85 & 249 & 4.42 & 1.61 & 36.36 \\
\hline & & Vaccinated & 73 & 10.96 & 2.74 & 25.00 & 229 & 1.31 & 0.44 & 33.33 \\
\hline \multirow{4}{*}{$\begin{array}{l}\text { Irrigated } \\
\text { Area }\end{array}$} & \multirow{2}{*}{ Buffalo } & Nonvaccinated & 69 & 31.88 & 18.84 & 59.09 & 164 & 4.27 & 2.44 & 57.14 \\
\hline & & Vaccinated & 132 & 9.09 & 3.78 & 41.66 & 314 & 1.59 & 0.32 & 20.00 \\
\hline & \multirow{2}{*}{ Cattle } & Nonvaccinated & 78 & 6.41 & 2.56 & 40.00 & 215 & 3.72 & 0.93 & 25.00 \\
\hline & & Vaccinated & 129 & 4.00 & 1.00 & 25.00 & 365 & 1.00 & 0.00 & 0.00 \\
\hline \multirow{4}{*}{ Sandy Area } & \multirow{2}{*}{ Buffalo } & Nonvaccinated & 62 & 16.13 & 4.84 & 30.00 & 143 & 2.79 & 0.69 & 25.00 \\
\hline & & Vaccinated & 81 & 3.71 & 0.00 & 0.00 & 130 & 0.77 & 0.00 & 0.00 \\
\hline & \multirow{2}{*}{ Cattle } & Nonvaccinated & 197 & 3.55 & 1.02 & 28.57 & 433 & 2.09 & 0.23 & 11.11 \\
\hline & & Vaccinated & 201 & 1.00 & 0.00 & 0.00 & 350 & 0.00 & 0.00 & 0.00 \\
\hline
\end{tabular}

$\mathrm{n}$ is the number of animals 
Table 5. Mean values of morbidity, mortality, and case fatality in different parameters under study (mean \pm standard error). Mean values followed by the same letter in the same column for each parameter (age, vaccination, and areas) do not vary significantly $(P<$ 0.05)

\begin{tabular}{|c|c|c|c|c|c|}
\hline Sr. No & Parameters & & Morbidity (\%) & Mortality (\%) & Case Fatality (\%) \\
\hline \multirow{3}{*}{1} & \multirow{3}{*}{ Age } & Young buffalo & $12.56 \pm 3.96^{\mathrm{a}}$ & $22.44 \pm 2.19^{\mathrm{a}}$ & $40.44 \pm 5.75^{\mathrm{a}}$ \\
\cline { 3 - 6 } & & Young cattle & $2.42 \pm 3.96^{\mathrm{b}}$ & $6.46 \pm 2.19^{\mathrm{b}}$ & $28.74 \pm 5.75^{\mathrm{ab}}$ \\
\cline { 3 - 6 } & & Adult buffalo & $0.94 \pm 3.96^{\mathrm{b}}$ & $2.82 \pm 2.19^{\mathrm{b}}$ & $25.68 \pm 5.75^{\mathrm{b}}$ \\
\cline { 3 - 6 } & & Adult cattle & $0.54 \pm 3.96^{\mathrm{b}}$ & $1.97 \pm 2.19^{\mathrm{c}}$ & $17.63 \pm 5.75^{\mathrm{c}}$ \\
\hline \multirow{2}{*}{2} & \multirow{2}{*}{ Vaccination } & Nonvaccinated & $6.89 \pm 2.79^{\mathrm{a}}$ & $12.13 \pm 2.96^{\mathrm{a}}$ & $39.99 \pm 4.06^{\mathrm{a}}$ \\
\cline { 3 - 6 } & & Vaccinated & $1.33 \pm 2.79^{\mathrm{b}}$ & $4.71 \pm 2.96^{\mathrm{b}}$ & $16.25 \pm 4.06^{\mathrm{b}}$ \\
\hline \multirow{3}{*}{3} & \multirow{3}{*}{ Areas } & Flood & $7.78 \pm 3.43^{\mathrm{a}}$ & $13.95 \pm 3.63^{\mathrm{a}}$ & $39.05 \pm 4.98^{\mathrm{a}}$ \\
\cline { 3 - 6 } & & Irrigated & $3.71 \pm 3.43^{\mathrm{a}}$ & $7.54 \pm 3.63^{\mathrm{b}}$ & $33.48 \pm 4.98^{\mathrm{b}}$ \\
\cline { 3 - 6 } & & Sandy & $0.84 \pm 3.43^{\mathrm{a}}$ & $3.76 \pm 3.63^{\mathrm{c}}$ & $11.84 \pm 4.98^{\mathrm{c}}$ \\
\hline
\end{tabular}

Table 6. Indirect hemagglutinating test titers against $\mathrm{HS}$ in buffalo and cattle of different geographical regions

\begin{tabular}{|c|c|c|c|c|c|c|c|c|c|c|c|c|c|}
\hline \multirow{2}{*}{ Species } & \multirow{2}{*}{ Area } & \multirow{2}{*}{ Vaccination status } & \multicolumn{10}{|c|}{ Distribution of animals on the basis of H.S. (IHA) titer } & \multirow[t]{2}{*}{ GMT } \\
\hline & & & 0 & 1 & 2 & 3 & 4 & 5 & 6 & 7 & 8 & 9 & \\
\hline \multirow{6}{*}{ Buffalo } & \multirow{2}{*}{ Flood } & Nonvaccinated & 5 & 6 & 8 & 14 & 17 & & & & & & 06.97 \\
\hline & & Vaccinated & & & & & 7 & 17 & 12 & 9 & 5 & & 33.18 \\
\hline & \multirow{2}{*}{ Irrigated } & Nonvaccinated & 2 & 7 & 13 & 9 & 6 & 13 & & & & & 08.88 \\
\hline & & Vaccinated & & & & & & 18 & 3 & 9 & 15 & 5 & 45.16 \\
\hline & \multirow{2}{*}{ Sandy } & Nonvaccinated & 2 & 7 & 2 & 4 & 16 & 17 & 2 & & & & 13.54 \\
\hline & & Vaccinated & & & & & & 8 & 11 & 16 & 9 & 6 & 47.33 \\
\hline \multirow{6}{*}{ Cattle } & \multirow{2}{*}{ Flood } & Nonvaccinated & 7 & 3 & 11 & 8 & 21 & & & & & & 07.08 \\
\hline & & Vaccinated & & & & & 3 & 19 & 8 & 5 & 11 & 2 & 38.03 \\
\hline & \multirow{2}{*}{ Irrigated } & Nonvaccinated & 6 & 1 & 11 & 12 & 15 & 5 & & & & & 08.29 \\
\hline & & Vaccinated & & & & & 4 & 6 & 8 & 9 & 14 & 9 & 49.00 \\
\hline & \multirow{2}{*}{ Sandy } & Nonvaccinated & 0 & 8 & 6 & 15 & 10 & 11 & & & & & 10.24 \\
\hline & & Vaccinated & & & & & 1 & 3 & 15 & 18 & 13 & & 45.97 \\
\hline
\end{tabular}

The morbidity, mortality, and CFR in all three study areas in nonvaccinated population (cattle and buffalo) were higher $(8.42 \%, 4.60 \%$, and $54.64 \%$ respectively) as compared with the vaccinated animal's (2.80\%, $0.76 \%$ and $27.27 \%$ respectively) (Table 3). The result agrees with former investigation that vaccination provides better immunity and reduce the morbidity, incidence rate, mortality and case fatality due to HS disease in the animal population $[17,23]$ also in the poultry vaccinated birds have less morbidity, mortality and case fatality as compared to the nonvaccinated $[19,20]$. Whereas, from buffalo in flood, irrigated and sandy areas, morbidity, mortality and case fatality of nonvaccinated animals $(14.33 \%, 9.04 \%$ and $63.08 \%$ respectively), vaccinated animal $(4.74 \%$, $1.38 \%$, and $29.18 \%$ respectively) (Table 3 ) greater from cattle population is not vaccinated $(4.18 \%, 1.42 \%$, and $33.96 \%$ respectively), and in vaccinated cattle $(1.34 \%, 0.30 \%$, and $22.22 \%$ respectively) (Table 3). Therefore it can be concluded from the findings that the buffalos are more susceptible to the diseases as compared to the cattle's $[9, \mathbf{1 6}]$. Moreover, the mortality, morbidity, and case fatality among nonvaccinated and vaccinated young buffalo in flood, irrigated and a sandy area greater than nonvaccinated and vaccinated adult population (Table 4). The same pattern was observed in nonvaccinated and vaccinated young and adult cattle in the different environmental 
area (Table 4). The same was observed previously that in young animal population the morbidity, mortality and case fatality was higher than adult animal population [16] this may be due to the better immune response or having already exposure of the microorganism from the environment or by vaccination.

It was noted that among the age group the morbidity, mortality and case fatality in young buffalo was significantly higher than young cattle except case fatality which has no significant difference with young buffalo. However, the adult group the mortality and case fatality was significantly higher in adult buffalo as compared with cattle [11]. Moreover, the nonvaccinated animal population has considerably higher morbidity, mortality and case fatality than vaccinated animal population (Table 5) [9]. Furthermore, the mortality, case fatality was significantly higher in flood area, and lesser in the sandy area (Table 5).

The comparative value of GMT against HS deducted with IHA test both for cattle and buffalo presented in (Table 6). GMT in vaccine status and category of animals showed that it was higher in vaccinated animal than nonvaccinated animal population. Moreover, the GMT was greater in the sandy area as compared with flood and irrigated area. Furthermore, the GMT for vaccinated buffalo was lesser as compared to the vaccinated cattle making them more susceptible to the disease. The results are in line with previously noted finding, the higher GMT values for cattle as compared to those of buffalo $[\mathbf{1 6}, \mathbf{1 8}]$.

\section{Conclusion}

The highly endemic nature of HS disease indicates its important in cattle and buffalo in Asia and Africa. The mortality and case fatality were high in HS disease unlike other livestock diseases, indicates the importance of disease in maintaining the overall animal assets and lively hood of livestock farmers. The control option mitigates the disease especially in more susceptible species (buffalo and cattle) and area (flood, irrigated and sandy) and if vaccination is planned and implemented based on the epidemiological results, the disease burden can be minimized. It can be concluded from the present investigation that HS is endemically occurring in cattle and buffalo. Buffalo are more susceptible of disease as compared to the cattle, moreover, the young population of buffalo and cattle highly affected (morbidity, mortality, and CFR) of HS as compared with the adult stock. It was also noted that the morbidity, mortality, CFR was greater in flood area, and lesser in a sandy area.

\section{Authors' contributions}

Conceived and designed the experiments: KU Rehman \& M Aziz, Performed the experiments: M Ahmad, Analyzed the data: RU Rehman, A Rehman, KU Rehman \& M Ahmad, Contributed materials/ analysis/ tools: RU Rehman, A Rehman, T Tunio, A Hameed, T Naveed, M Tanveer \& M Ali, Wrote the paper: KU Rehman.

\section{References}

1. Tariq $\mathbf{M}$, Younas $\mathrm{M}$, Khan $\mathrm{AB}$ \& Schlecht E (2013). Body measurements and body contition scoring as a basis for estimation of live weight in Nilli-Ravi buffalloes. Pak Vet J 33: 325-329.

2. Mustafa H, Khan WA, Heather HJ \& Kuthu H (2018). Performance of bovine high density SNPs genotyping array in indigenous Pakistani cattle breeds. Pure Appl Biol 7: 221-226.

3. Economic Survey of Pakistan (201617). Pakistan Economic Survey, 201617 pp 19-40.

4. GoP (2016). Economic Survey of Pakistan. Pakistan Economic Survey (2015). Pakistan Economic Survey 2014-15.

5. Hussain, R, Javed, MT \& Khan, A (2012). Changes in some biochemical parameters and somatic cell counts in the milk of buffalo and cattle suffering from mastitis. Pak Vet J 32: 418-421.

6. Ashfaq M, Razzaq A, Hassan S \& Haq $S$ (2015). Factors affecting the economic losses due to livestock diseases: A case study of district 
Faisalabad. Pak J Agric Sci. 52: 515520.

7. Benkirane A \& De Alwis M.C.L (2002). Hemorrhagic septicemia, its significance, prevention and control in Asia. Vet Med (Praha) 47: 234-240.

8. Moustafa AM, Ali SN, Bennett MD \& Hyndman TH (2017). A Case-control Study of Haemorrhagic Septicaemia in Buffaloes and Cattle in Karachi, Pakistan, in Transbound. Emerg. Dis 64: 520-527.

9. Singh B, Shiv Prasad, Med RV \& Sinha DK (2014). Estimation of Economic Losses due to Haemorrhagic Septicaemia in Cattle and Buffaloes in India. Agric Econ Res Rev 27: 271279.

10. Shivachandra SB, Viswas KN \& Kumar AA (2011). A review of hemorrhagic septicemia in cattle and buffalo. Anim Health Re Rev 12: 6782.

11. Khan A, Saddique U, Ahmad R \& Khan H (2006). Sero-surveillance of Hemorrhagic Septicemia in Cattle and Buffaloes in District Malakand, NWFP. J Agric Biol Sci 1: 11-14.

12. Khan A, Saleemi MK, Khan MZ \& Gul ST (2011). Hemorrhagic septicemia in buffalo (Bubalus bubalis) calves under sub-tropical conditions in Pakistan. Pak J Zool 43: 295-302.

13. Sattar R S, Wang S, Tahir, M N \& Caldwell C (2017) Assessment of smallholder farmer's vulnerability due to climate change in arid areas of Pakistan. Appl Ecol Environ Res 15: 122.

14. Arif N, Geof W \& Ghaus MU (2017). Geography of Poverty in Pakistan: Explaining regional inequality.

15. Farooq U, Saeed Z, Khan MA \& Ali I (2011). Sero-surveillance of hemorrhagic septicemia in buffaloes and cattle in southern Punjab, Pakistan.
Pak Vet J 31: 254-256.

16. Qureshi S \& Saxena HM (2014). Estimation of titers of antibody against Pasteurella multocida in cattle vaccinated with hemorrhagic septicemia alum precipitated vaccine. Vet World 7: 224-228.

17. Farooq U, Hussain M, Irshad H, Badar N, Munir R \& Ali Q (2007). Status of hemorrhagic septicemia based on the epidemiology in Pakistan. Pak Vet $J$ 27: 67-72.

18. Kashif-ur Rehman, Ahmad MD, Raza MA \& Ahmad MJ (2014). Effects of infectious bursal disease vaccine on the immunity induced by Newcastle disease vaccine in broiler birds. Sci Int 31: 165-169.

19. Kashif-ur Rehman, Ahmad M, Raza M, Murtaza S \& Abbas I (2014), IBD Vaccination Schedule Upshots on Immunity Tempted by ND Vaccination In Poultry. Sci Int (Lahore) 26: 307310.

20. Brugh MA (2011). A simple method for recording and analyzing serological data. Avian Dis 22: 362-5.

21. Govindaraj G, Krishnamoorthy P, Nethrayini KR \& Shalini R (2017). Epidemiological features and financial loss due to clinically diagnosed Haemorrhagic Septicemia in bovines in Karnataka, India. Prev Vet Med 144: 123-133.

22. Rathod P, Chander M \& Desai BA, (2013). Vaccination strategy for prevention and control of economically important livestock diseases in Karnataka. Indian J F Vet 8: 29-33.

23. Saleem L, Munir R \& Ferrari G (2014). Efficacy and cross-protectivity of live intranasal aerosol hemorrhagic septicemia vaccine in buffalo calves. Int J Curr Microbiol App Sci 3: 300307. 